\title{
Difficulties and Problems of Street Children
}

\author{
Pratibha $^{1}$, A. Mathur ${ }^{2}$, Ansu $^{3}$ \\ Research Scholar, SHIATS, Allahabad, India \\ Assistant Professor, SHIATS, Allahabad, India \\ Associate Professor, SHIATS, Allahabad, India
}

\begin{abstract}
A street child in India is someone "for whom the street has become his or her habitual abode and/or source of livelihood; and who is inadequately protected, supervised, or directed by responsible adults. Mainly because of family conflict, they come to live on the streets and take on the full responsibilities of caring for themselves, including working to provide for and protecting themselves. Though street children do sometimes band together for greater security, they are often exploited by employers and the police. The purpose of this study was to assess the difficulties and problems of street children. A descriptive research design and cross sectional survey method was used to collect data from a total of 260 samples comprising of 130 boys and 130 girls from slums areas using self made questionnaire.
\end{abstract}

Keywords: Street Children"s, Gender, Demographics

\section{Introduction}

Majority of us are blessed because when we return home from offices, colleges and schools there is a family waiting for us which takes away our tiredness. But all are not that fortunate. Many children in India are deprived off this feeling of family and home. We celebrate every occasion but wonder how street children spend their life and celebrate festivals. They spend their entire life near bus station, railway station, markets, on footpaths, streets etc. Though a well-structured data and number is not available but it is estimated that India has more than 4,00,000 street children. Also India has the largest population of street children in the world. According to Rajan Saxena (2006)-Lifestyle refers to the beliefs, attitudes,interests, and opinions that an individual has about himself, his family, and the world ( $p$. 173). It is - a concept that refers to alternative ways of living, usually conspicuous through values and modes of consumption (Scott \& Marshall, 2005, p. 365).In another words, - lifestyle refers to the physical, mental and spiritual actions of a man on a day-to-day basis, , (Jain, 2007, p. 7). Street children are among the most physically visible of all children, living and working on the roads and public squares of cities all over the world Unicef (2006). Street children is a term for children experiencing homelessness who live on the streets of a city, town or village. Homeless youth are often called street kids and street youth. India has an estimated one million or more street children in each of the following cities: New Delhi, Kolkata, and Mumbai. Owing to unemployment, increasing rural-urban migration, the attraction of city life, and a lack of political will, India has developed one of the largest child labor forces in the world. These floating children are often subject to discrimination, beating/torture and sexual harassment (Gupta, 2000). Definition of a Street Child by UNICEF, “... any girl or boy... for whom the street (in the widest sense of the word, including unoccupied dwellings, wasteland, etc.) has become his or her habitual abode and/or source of livelihood; and who is inadequately protected, supervised, or directed by responsible adults". Female street children are sometimes called gamines, a term that is also used for Colombian street children of either gender. Francise
Remington (1993) said that over 120 million children live in the cities and towns of South Asia. Denied their rights, enshrined in the CRC and deprived of basic services, many of them suffer extremely from exploitative and violent conditions.

\section{Causes}

The causes of this phenomenon are varied, but are often related to domestic, economic, or social disruption including, but not limited to, poverty; breakdown of homes and/or families; political unrest; acculturation; sexual, physical or emotional abuse; domestic violence; lured away by pimps, Internet predators, or begging syndicates; mental health problems; substance abuse; and sexual orientation or gender identity issues. This study illustrates the trend found by most researchers: most children leave their families to live on the street because of family problems. Family problems include such things as death of a parent, alcoholism of father, strained relationships with stepparents, parent separation, abuse, and family violence. Additionally, street children usually come from female-headed households. They may be categorized into street living children, street working children and children at risk of coming to the streets (Ferguson, 2012). found that rejected children indulge themselves more often in delinquent behaviour and are more aggressive than overprotected children. Such children become withdrawn or distractible, hyperactive and have night terrors, while some of them run away from home. Sometimes they exhibit a mixture of submissiveness, aggressiveness, insecurity, sadistic tendencies, shyness, stubbornness and non-compliance. Symonds (1993).

\section{Difficulties \& Problems}

Lack of Adequate Nutrition: street children can usually get some amount of food to eat, they do not have nutritious or balanced diets. This deficiency thus manifests itself in the form of anemia, malnutrition, and vitamin deficiencies). 


\section{International Journal of Science and Research (IJSR) \\ ISSN (Online): 2319-7064 \\ Index Copernicus Value (2013): 6.14 | Impact Factor (2014): 5.611}

Homelessness: The children who choose the streets as their home face the most acute problems related to shelter. They are vulnerable to all ranges of weather conditions be it the burning heat of summer, the rainstorms or the chilly winter nights. These children do not suffer merely from physical homelessness, but also from a psychological homelessness since they have ,nowhere to belong ${ }^{\text {ee }}$.

Health Problems: Street children live in an atmosphere of continued physical and mental strain. Many of them rummage through the garbage to find food; others go hungry for days drinking water or taking to drugs to diminish their pangs of hunger.

Substance Abuse: Many street children resort to using psychoactive substances (such as alcohol and drugs) in an attempt to escape from the overwhelming pressure of their traumatic past and their daily problems.

Deprivation of Needs and Lack of Resources and Opportunities: The varied needs of street children are rarely met. They frequently go hungry; wear torn, tattered and dirty clothes or sometimes, no clothes at all. They have no permanent place to stay, no educational facilities, no facilities for hygiene and in brief, no facilities at all.

Exploitation: Children on the street have to work to survive. Since they have no skills with which to bargain for fair pay or to fight for their rights, they are very vulnerable to employers who look to make a profit on them. Weiner, Myron (1991) felt that child labour and the presence of children on the streets must be seen as less a phenomenon of poverty and more of phenomenon of social attitudes, exploitation, compulsions and sensibilities.

\section{Materials and Method}

A Descriptive Research Design was followed to conduct the present study and cross sectional survey method was used to collect data from the selected sample. The study will we conducted at Faizabad as the researcher is acquainted and familiar with the place. Various slums of Faizabad districts will be selected using random sampling technique to draw the sample. Children in to the age group of $5-15$ years children will be selected from different slums. A total sample of 260 children comprising of 130 boys and 130 girls respectively will be selected for the study.

\section{Results and Discussion}

Table 1: Percentage and frequency distribution of number of respondents of family members

\begin{tabular}{|c|c|c|}
\hline No of family members & frequency & percentage \\
\hline $1-4$ & 50 & 19.23 \\
\hline $5-7$ & 76 & 29.23 \\
\hline $7-10$ & 79 & 30.38 \\
\hline 10-above & 55 & 21.15 \\
\hline Total & $\mathbf{2 6 0}$ & $\mathbf{1 0 0 . 0 0}$ \\
\hline
\end{tabular}

In our study I found that, the table shows that the majority of street child $30.38 \%$ in their family members 7-10 and minimum numbers of family members $19.23 \%$ whose belongs to 1-4 person in the family.
Table 2: Percentage and frequency distribution of total number of children in the respondent family

\begin{tabular}{|c|c|c|}
\hline No. of children's & frequency & percentage \\
\hline $1-3$ & 42 & 16.15 \\
\hline $4-7$ & 102 & 39.23 \\
\hline $7-10$ & 66 & 25.38 \\
\hline 10 -above' & 50 & 19.23 \\
\hline Total & $\mathbf{2 6 0}$ & $\mathbf{1 0 0 . 0}$ \\
\hline
\end{tabular}

The above table shows percentage of total numbers of children in respondent family. The results are the majority of $(39.23 \%)$ respondents were in the family number of children group 4-7 as compared to the respondent minimum $(16.15 \%)$ number of family children.

Table 3: Percentage and frequency distribution of respondent having second mother

\begin{tabular}{|c|c|c|}
\hline Respondents & frequency & percentage \\
\hline No & 79 & 30.38 \\
\hline Yes & 109 & 41.92 \\
\hline Don $^{\text {"c } \text { know }}$ & 72 & 27.69 \\
\hline total & 260 & 100.00 \\
\hline
\end{tabular}

Table reveals that the percentage distribution of respondent who having second mother or not. In the table shows that the majority of $41.92 \%$ of respondents having second mother and as compared to $30.38 \%$ respondent street children not having second mother. $27.69 \%$ street children did not know about our parent.

Table 4: Frequency distribution and percentage of respondents age as a street children

\begin{tabular}{|c|c|c|}
\hline No of respondents & frequency & percentage \\
\hline By birth & 28 & 10.76 \\
\hline Second to fourth year & 55 & 21.15 \\
\hline Fourth to six year & 107 & 41.15 \\
\hline Six to ten or above & 70 & 26.92 \\
\hline Total & $\mathbf{2 6 0}$ & $\mathbf{1 0 0 . 0 0}$ \\
\hline
\end{tabular}

It is seen that the above table the percentage and frequency distribution of respondent as a street children the majority of $41.15 \%$ children started a life as a street children their age group of four to six year. Minimum $10.76 \%$ children started a life as street children their age group of by birth. $26.92 \%$ respondent age six to ten or above when they start life as street children.

Table 5: Frequency distribution of respondent as to their parent live together

\begin{tabular}{|c|c|c|}
\hline No. of respondents & Frequency & Percentage \\
\hline Divorced & 79 & 30.38 \\
\hline Yes & 84 & 32.30 \\
\hline No & 50 & 19.23 \\
\hline Don't know & 47 & 18.07 \\
\hline Total & 260 & 100.00 \\
\hline
\end{tabular}

It can be noted down from the above table that the majority of $32.30 \%$ respondent were parent live together and 19.23 $\%$ respondent were live without parents. $30.38 \%$ respondent children whose their parent divorced. 


\section{Conclusion}

Assess the impact of street children and the associated problems It has been argued that overall the problem is large, but if looked at from a community perspective it is not insurmountable. Poverty and gender discrimination are the prime causes of the street children crisis. To reach street children who generally lack access to public school services due primarily to poverty. These children have also limited access to food, shelter, protection, and health. Through the Street Education Program of Child hope, they will be assisted and provided basic education and meals. Childhope will also encourage the street youth to engage in different livelihood/service skills training that will help them to have a sustainable job and have an income generating activities.

\section{References}

[1] K. M. Ferguson (2012), Children in and of the Street,\| Handbook of International Social Work: Human Rights, Development and Global Profession, L. M. Healy and R. J. Link, eds., New York, NY: Oxford University Press,pp. 160 -165, 2012.

[2] According to Wikipedia the free encyclopedia(2012) - street children in India.

[3] R. K. Jain (2007) Lifestyle for Total Development: A Unique Guide to Develop Your Personality. New Delhi, India: Sterling Publishers, p. 7, 2007

[4] R. Saxena, (2006) Marketing Management. $3^{\text {rd }}$ ed. India: Tata McGraw-Hill Publishing Limited,p. 173, 2006.

[5] Unicef (2006) the state of a worlds children

[6] D. Gupta (2005) Baseline Survey of Street Children of Dhaka City: A report. Lalmatia, Dhaka: World Vision/DSL, p. 1, 2000.

[7] J. Scott and G. Marshall (2005) Oxford Dictionary of Sociology. Oxford: Oxford University Press, p. 365, 2005

[8] UNICEF (2004) Prevalence, Abuse and Exploitation of Street Children (PDF report).

[9] Asha Das (2000), Proceedings of the Workshop; On a Situational Analysis of Education for Street and Working Children in India, UNDP Conference (New Delhi).

[10] Dr. Zutshi (2000), Analysing Education for Street and Working Children; A workshop, UNESCO,New Delhi, News Letter Vol9, No.4 December 200.0. Pioneer, (2000) "of the street," New Delhi.

[11] Educating Street Children: Indian Experience", Special Article, Monthly Public Opinion, December 2000, VXLVI, No.3, p. 6.

[12]Joseph, C., (1995), Scarlet Wounding: Issues of Child Prostitution, in Journal Of Psychohistory 23 (1) (2-17).

[13] Irene Rizzini, Mark W. Lusk (1995), Children in the streets: Latin America's lost generation, Children and Youth Services Review, , Volume 17, Issue 3, Pp 391400.

[14] Desai (1995), Physical abuse, sexual victimization and illicit drug use replication of structural analysis among a new sample of High-Risk youths, Violence and victims, Vol. 4, No.2.
[15] Asha Rane J. (1994), editor street children: a challenge to the social work profession. Bombay: Tata Institute of Social Sciences,

[16] Nigam.S. (1994), Street children of India - a glimpse. Journal of Health Management. 1994 Jan-Jun;7(1):637.

[17] Symonds (1993), Forging Links: Effective Schools and Effective Departments, London: Paul Chapman. Consortium of street children (1993)

[18] Remington F. (1993), The forgotten ones. A story of street children and schooling in South Asia. Integration. 1993 Sep, (37). 40-2.

[19] Weiner, Myron (1991), The child and the state in India, child labour and education policy in comparative perspective Princeton University Press, Princeton. 